\title{
Pulmonary malakoplakia associated with immunodeficiency by HTLV-1 and HIV
}

\section{Malacoplaquia pulmonar associada à imunodeficiência por HTLV-1 e HIV}

Manuela Madruga'; Janaina Nagel²; Cristiane Bedran Militoº ${ }^{3}$ José Carlos Morais ${ }^{4}$

\begin{abstract}
Malakoplakia is a rare chronic inflammatory disease often confused with neoplasia. In this paper we report two cases of pulmonary Malakoplakia, both with typical clinical diagnosis of tuberculosis and lung cancer. A patient with human T-lymphotropic virus type I (HTLV-1) and diagnosis of adult T-cell leukemia/lymphoma, and another patient with human immunodeficiency virus (HIV), which was treated for tuberculosis, but, after pulmonary lobectomy, was evidenced Rodococosis equi, progressed to death.
\end{abstract}

Key words: malakoplakia; immunodeficiency; HTLV-1; HIV; pulmonary infection; Rhodococcus equi.

\section{INTRODUCTION}

Malakoplakia is a rare chronic granulomatous inflammatory disease of uncertain etiology, although studies point to failure in bacterial lysis in the lysosomes of macrophages, and the coexistence of immunossupression. Biopsy is essential in the differential diagnosis of malakoplakia and other diseases, in order to define appropriate therapeutic measures. In this paper, we report two cases of malakoplakia with pulmonary involvement. The first case report is in a patient with adult T-cell leukemia/lymphoma and human T-lymphotropic virus type I (HTLV-1); and the second case report is in a patient with human immunodeficiency virus (HIV), both evolving to death.

\section{CASE REPORT 1}

Female patient, 52 years of age, white, with back pain, dry cough, hemoptysis, hoarseness, left-side chest pain, and weight loss. Chest X-rays showed a hypotransparent image of $4 \mathrm{~cm}$ in diameter, at the left lung apex (Figure 1), and a mass in the lumbar region. After resection, the lung mass was diagnosed as malakoplakia. Subsequently, the patient was admitted with fever, cough, dyspnea, and weight loss. Serology for anti-HIV 1 and 2 were negative, $37600 / \mathrm{mm}^{3}$ of leukocytosis with $60 \%$ of lymphocytes with small circulating cells with irregular nucleus (Figure 2), hematocrit (Ht) $36 \%$, hemoglobin (Hb) $12 \mathrm{~g} / \mathrm{dl}$, and platelets 306000/. $\mathrm{mm}^{3}$. Biopsy of bone marrow with focal infiltration of lymphocytes similar to those in peripheral blood is showed in Figure 3. Immunophenotyping of peripheral blood lymphocytes showed CD25-94\%, CD3-96\%, $\mathrm{CD} 3 / 4-93 \%, \mathrm{CD} 3 / 8-2 \%$, CD21-1\%, and CD20/21-1\%. The analysis for HTLV-1 was positive, and the adult T-cell leukemia/lymphoma (HTLV-1) diagnosis was performed. Pulmonary malokoplakia diagnosis (Figure 4) was performed at autopsy.

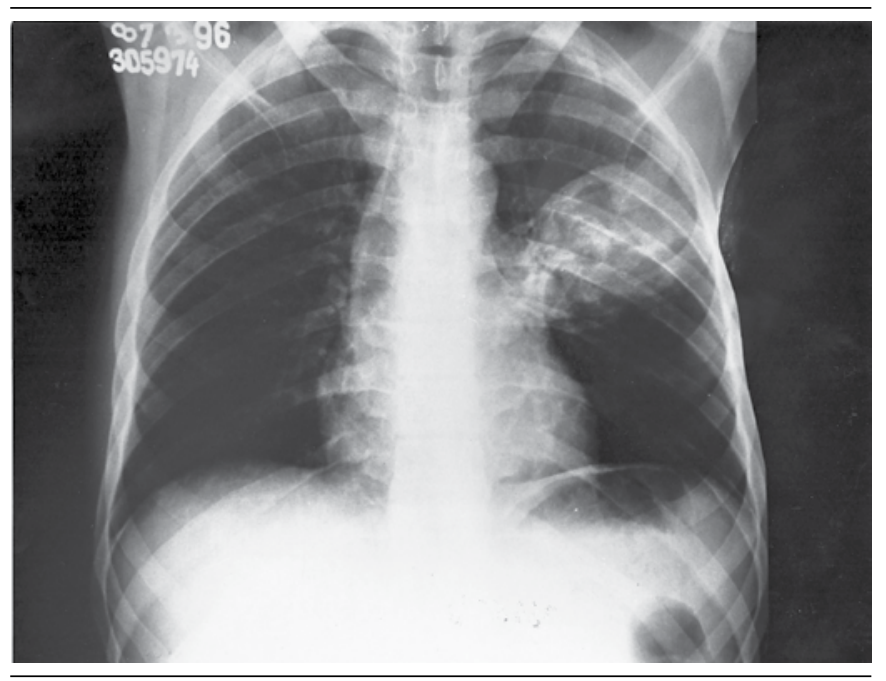

FIGURE 1 - Chest Radiography showing heterogeneous opacity in the anterior segment of the left upper lobe, rounded, with ill-defined borders, measuring about $6 \mathrm{~cm}$ 


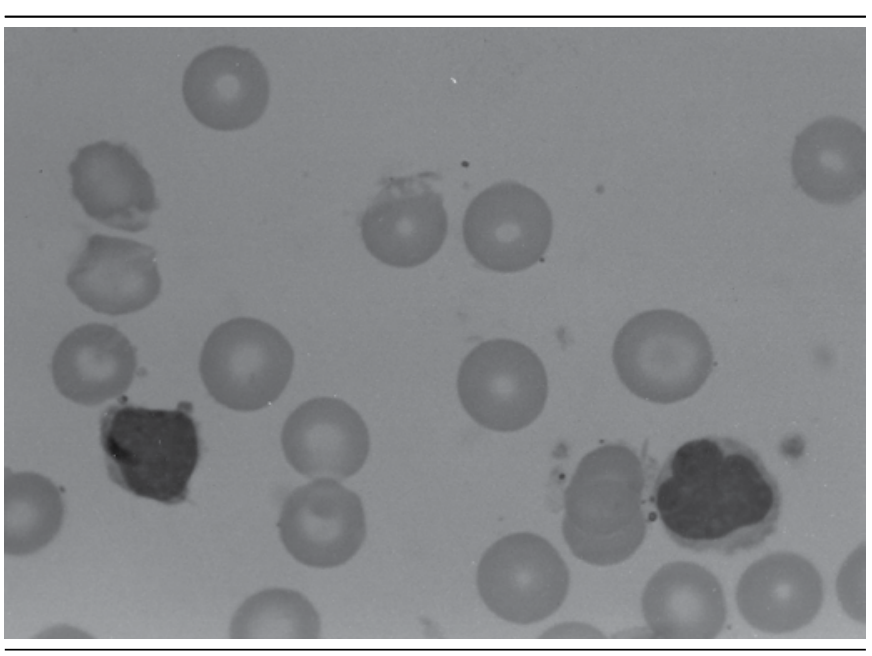

FIGURE 2 - Peripheral blood with small circulating lymphocytes, with irregular nucleus

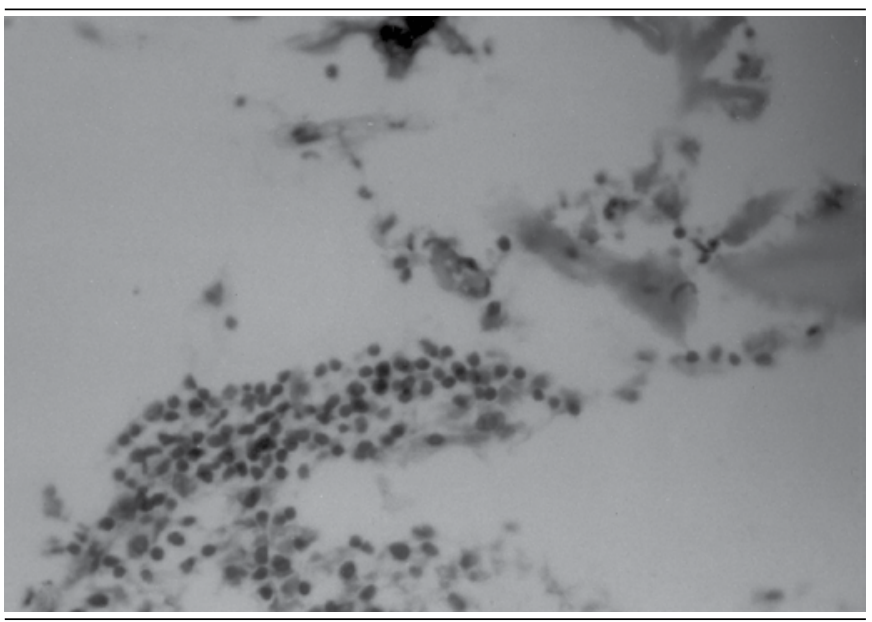

FIGURE 3 -Bone marrow biopsy shows focal infiltration with lymphocytes similar to those in the peripheral blood

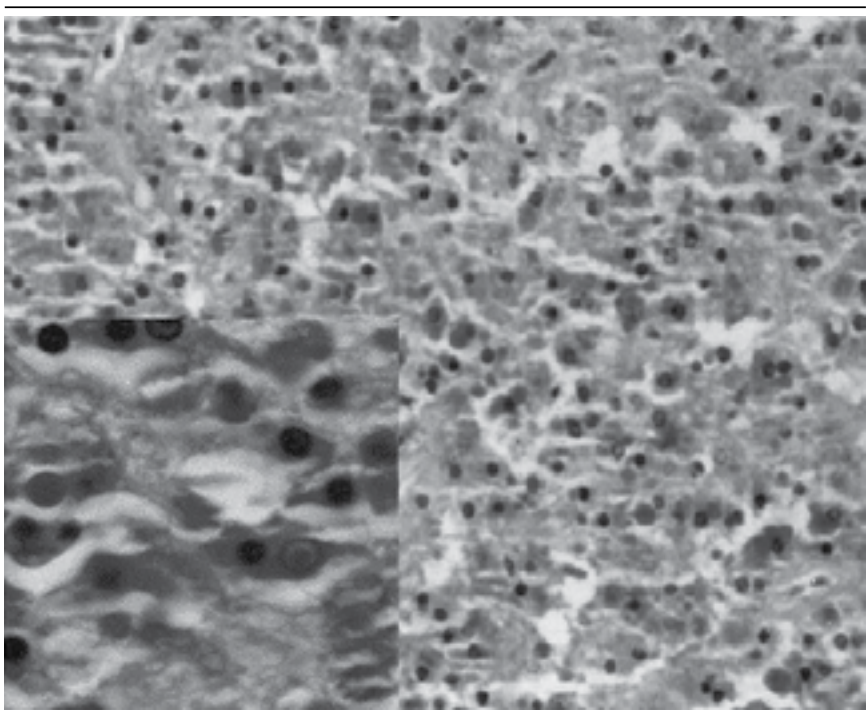

FIGURE 4 -Lung lesions consisted of mononuclear cells proliferation, mainly at the expenses of bistiocytes, plasmocytes, and lymphocytes, with fibroblast proliferantion got in the way (PAS, 100×). In the liner notes, presence of basophilic corpuscles, PAS+ (Michaelis-Gutmann bodies) (PAS, 400 $)$ PAS: periodic acid-schiff.

\section{CASE REPORT 2}

Male patient, 29 years of age, black, presented psychiatric disorder (aggressiveness), and, clinically, cough, purulent sputum, fever, and consumptive syndrome and oral candidiasis. Diagnostic investigation revealed pulmonary cavitary lesion in the upper lobe of left lung, and positive serology for anti-HIV. Established trial therapy for pulmonary tuberculosis, he evolved with clinical and radiological worsening after two months of treatment. Given this and the negativity of new microbiological examinations, it was indicated pulmonary lobectomy, with hypothesis of mycetoma in tuberculous cavity. Sputum examination showed Candida $s p$. yeast. In pulmonary specimen was diagnosed malakoplakia (Figure 5), and Rhodococcus equi isolated. During three months, he received medication for secondary prophylaxis to Rodococose, when progressed to death.

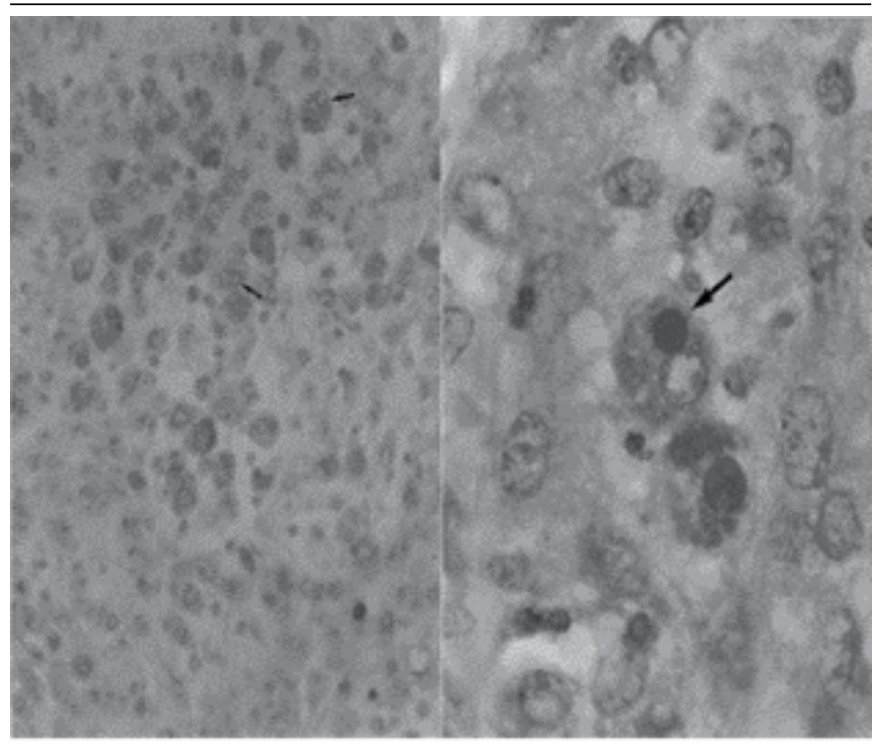

FIGURE 5 - Histiocytes with cytoplasmic positivity for CD68 antigen. Negative image, in the cytoplasm, corresponds to Michaelis-Gutmann bodies (Imunoperoxidase, 400×). In detail, von Hansemann bistiocytes containing Michaelis-Gutmann bodies (PAS, 1000×) PAS: periodic acid-schiff.

\section{DISCUSSION}

Malakoplakia is a rare chronic granulomatous inflammatory disease $^{(1,10)}$, macroscopically reported as yellow-gray plates, composed of aggregates of histiocytes ${ }^{(7,10)}$, as first described in the bladder, in 1902, by Michaelis and Gutmann. Currently, intracellular basophilic inclusions, known as Michaelis-Gutmann bodies (MG bodies), found in von Hansemann histiocytes, are pathognomonic for malakoplakia ${ }^{(1,7,9)}$. This shows bimodal 
incidence in age, with prevalence below 13 years of age, and in middle-aged adults, which are more affected than children. The average age of diagnosis is 50 years, with no hegemony between gender $^{(9,10)}$. In cases presented here, both patients were adult, with 52 and 29 years of age.

Although malakoplakia can affect many organs, it occurs most commonly in the urinary tract, representing $58 \%-80 \%$ of all cases. Within this prevail in descending order: bladder, ureter, pelvis, and renal parenchyma $a^{(1,3,6,10,11)}$. The gastrointestinal tract and retroperitoneal region are the secondary most affected sites (12\%-15\%) by the disease. Other locations are less affected such as brain, bone, lung, adrenal glands, thyroid, eyeball, among others ${ }^{(3,4,11)}$.

Gupta et al. reported, in 1972, the first case of pulmonary malakoplakia, which showed multiple nodules in lower lobe, simulating metastasis ${ }^{(5)}$. Since then, only 17 cases have been reported. It may be present as a mass, simulating tumors, abscesses, or tuberculosis. Clinically, it varies from silent nodules to different manifestations, simulating bronchogenic carcinoma or tuberculosis. Malakoplakia should always be considered as a differential diagnosis, in order to prevent misinterpretation of large nodules with fast growth, such as tumors, avoiding unnecessary and radical surgeries ${ }^{(4,8)}$. Our cases report presented fever, cough, hemoptysis, weight lost, and chest pain, suggestive of neoplasia, tuberculosis, and e pneumonia.

Regarding the urinary tract, the infectious agents most commonly involved are Gram-negatives, mainly Escherichia coli (70\%-80\% of cases). In lungs, $R$. equi are predominat, especially in patients with acquired immunodeficiency syndrome (AIDS), which is the single bacterium isolated. One patient had Pneumocistis carinii in transbronchical biopsy, and in the other patient Candida $s$. was detected during bacterioscopy of sputum smear, and R. equii in the pulmonary mass.
Although there are underlying diseases identified for triggering a major role in the emergence of malakoplakia, its pathogenesis remains unknown, with several theories that try to explain it. The most accepted theory holds that chronic bacterial infections in patients with chronic weakness or immunosuppression would cause a deficit of cyclic guanosine monophosphate (cGMP) in microtubule and defective macrophage, causing them to phagocyte bacteria, but, in contrast, they would be unable to digest them due to intra-lisosomal failure. This situation would lead to intracytoplasmic deposition of fragments from bacteria, iron, and calcium, which would form the MG bodies ${ }^{(1,3,6,9)}$. In support of this theory, many studies state that these inclusions represent intake and persistence of bacteria in macrophages ${ }^{(4,5)}$. One patient in this study had HTLV-1 infection (adult T-cell leukemia/lymphoma), and the other by HIV, i.e., both immunocompromised.

Histologically, lesions are mostly formed of collections of histiocytes with abundant, slight staining and vacuolated cytoplasm, and eosinophil granule cells (Von Hansemann cells) arranged beneath the epithelium surface. Some of these cells may contain amorphous, rounded cytoplasmic inclusions, with centers of concentric membranes, which are bacteria fragments with target or owl eye aspect, they are basophilic and PAS (periodic acid-Schiff) positives. Because they contain ferric salt and phosphate salt deposits, they are positive, respectively, to Pearls and Von Kossa, known as MG bodies ${ }^{(1,3,8,10,11)}$. It is also known, by the experience of most authors, that MG bodies are easily recognized by Papanicolaou, Diff-Quik, and hematoxylin-eosin staining ${ }^{(2)}$.

Eventually, regarding malakoplakia treatment, it is worth remembering that it is a self-limiting disease and, most often, with good prognosis. Therefore, it relies on eliminating the main etiological agents currently credited, and discontinuing immunosuppressive mechanism, when possible. Surgical treatment is reserved just to eliminate possible complications ${ }^{(4,7,9,11)}$.

\section{RESUMO}

Malacoplaquia é uma rara doença inflamatória crônica muitas vezes confundida com neoplasia. Neste artigo, relatam-se dois casos de malacoplaquia pulmonar, ambos com quadro clínico sugestivo de tuberculose e neoplasia pulmonar. Uma paciente com vírus T-linfotrópico bumano tipo I (HTLV-1) e diagnóstico de leucemia/linfoma de células T do adulto, e um paciente com vírus da imunodeficiência bumana (HIV), tratado para tuberculose, mas após lobectomia pulmonar foi evidenciado Rodococose equi, evoluindo para óbito.

Unitermos: malacoplaquia; imunodeficiência; HTLV-1; HIV; infecção pulmonar; Rhodococcus equi. 


\section{REFERENCES}

1. AUN, J. J. F.; OLIVEIRA, M. B. B.; AUN, M. M. F. Malacoplaquia intestinal. Rev Col Bras Cir, v. 25, n. 2, 1998.

2. BISHOPRIC, G. A. et al. Pulmonary pseudotumor due to Corynebacterium equi in a patient with the acquired immunodeficiency syndrome. Thorax, v. 43, n. 6, p. 486-7, 1988.

3. BOUGUILA, J. et al. Digestive malacoplakia in children: case report. ISRN Gastroenterol, 2011.

4. GUPTA, K; THAKUR, S. Pulmonary malakoplakia: a report of two cases. Indian J Pathol Microbiol, v. 54, n. 1, p. 133-5, 2011.

5. GUPTA, R.; SCHUSTER, R.; CHRISTIAN, W. Autopsy finding in a unique case of malakoplakia. Arch Pathol, v. 93, p. 42-8, 1972.
6. HONSOVA, E. et al. Cured malakoplakia of the renal allograft followed by long-term good function: a case report. Biomed Pap Med Fac Univ Palacky Olomouc, v. 156, n. 2, p. 180-2, 2012.

7. KIM, P. T. et al. Colonic malakoplakia in a liver transplant recipient. Can J Gastroenterol, v. 21, n. 11, p. 753-5, 2007.

8. MCCLURE, J. Malakoplakia of the gastrointestinal tract. Postgrad Med J, v. 57, n. 664, p. 95-103, 1981.

9. PATNAYAK, R. et al. An unusual case of bilateral hydroureteronephrosis caused by uretero-vesico malakoplakia in a young male: a case report and review of the literature. Cases J, v. 2, n. 7527, 2009.

10. POZO MENGUAL, B. et al. Malacoplaquia vesical con afectación ganglionar y curso agresivo. Actas Urol Esp, v. 27, n. 2, p. 159-63, 2003.

11. VENTURA, et al. Malacoplaquia diseminada: evolución excepcional de una rara patología. Rev Méd Urug, v. 27, n. 1, 2011. 